\title{
Faktor-Faktor Yang Berhubungan Dengan Kejadian Ruptur Perineum Dalam Proses Persalinan Normal
}

\author{
Femmy Keintjem ${ }^{1}$, Atik Purwandari ${ }^{1}$, Novia Alida Lantaa ${ }^{1}$ \\ ${ }^{1}$ Jurusan Kebidanan Poltekkes Kemenkes Manado \\ Email : atikpurwandari75@gmail.com
}

\begin{abstract}
ABSTRAK
Latar Bekalang: Perdarahan postpartum menjadi penyebab utama $40 \%$ kematian ibu di Indonesia. Robekan jalan lahir merupakan penyebab kedua perdarahan setelah atonia uteri yang terjadi pada hampir persalinan pertama dan tidak jarang juga pada persalinan berikutnya. kejadian rupture perineum cukup tinggi di wilayah kerja Puskesmas Ranomut Kecamatan Paal II Manado.

Tujuan: Penelitian ini untuk menganalisis faktor-faktor yang berhubungan dengan kejadian ruptur perineum dalam proses persalinan normal.

Metode: Penelitian ini mengunakan desain penelitian retrospektif. Populasi dalam penelitian ini adalah semua ibu bersalin normal tahun 2016 di Puskesmas Ranomut Kecamatan Paal II Manado, dengan pengambilan sampel secara Total sampling. Analisa data menggunakan uji Chi square $\left(\mathrm{X}^{2}\right)$.

Hasil: Penelitian diperoleh hubungan bermakna antara pertus presipitatus dan rupture perineum dengan $p$ value 0,000 atau nilai $p<0,05$, terdapat hubungn bermakna antara paritas dan rupture perineum dengan $p$ value 0,005 atau nilai $p<0,05$, dan terdapat hubungan bermakna antara BBL dan rupture perineum dengan $p$ value 0,003 atau nilai $p<0,05$.

Kesimpulan: Terdapat hubungan yang signifikan antara partus presipitatus, paritas dan berat badan lahir dengan kejadian ruptur perineum. Disarankan para bidan dapat mempertahankan mutu pelayanan kebidanan dalam menangani persalinan sesuai APN agar proses persalinan berlangsung dengan normal tanpa komplikasi.
\end{abstract}

\section{Kata Kunci : Ruptur Perineum dan Persalinan Normal}

\section{PENDAHULUAN}

Berdasarkan Hasil Survey Demografi dan Kesehatan Indonesia (SDKI) tahun 2007, jumlah Angka Kematian Ibu (AKI) sebesar 228/100.000 Kelahiran Hidup (KH) dan mengalami peningkatan pada tahun 2012 sebesar 359/100.000 KH. Angka ini masih tinggi bila dibandingkan dengan target Sustainable Development Goals (SDG'S) tahun 2019 AKI sebesar 306/100.000 KH.
Berdasarkan Data Profil Kesehatan Provinsi Sulut tahun 2014 jumlah kematian ibu sebanyak 58 ibu dan penyebab kematian ibu yaitu perdarahan 17 (29\%), hipertensi dalam kehamilan 17 (29\%), infeksi $2(3 \%)$, abortus $2(3 \%)$, partus lama 1 (2\%), sebab lain-lain 19(34\%) (Dinas Kesehatan Provinsi Sulut, 2014). Kemudian mengalami peningkatan pada tahun 2015, dimana jumlah kematian 
ibu sebanyak 81 ibu dengan penyebab kematian ibu yaitu perdarahan 25 (31\%), hipertensi dalam kehamilan 14 (18\%), infeksi 6 (7\%), dan lain-lain 36 (44\%).

Kota Manado tahun 2014 jumlah kematian ibu 11 kasus dengan penyebab kematian yaitu perdarahan 1 (9\%), hipertensi dalam kehamilan 2 (19\%), abortus 1 (9\%), dan lain-lain 7 (63\%) (Dinas Kesehatan Kota Manado, 2014). Kemudian tahun 2015 jumlah kematian ibu meningkat mencapai 12 kasus dengan penyebab kematian ibu yaitu perdarahan 1 (8\%), hipertensi dalam kehamilan 4 (34\%), abortus $1(8 \%)$, dan lain-lain $6(50 \%)$.

Berdasarkan hasil survey data awal yang dilakukan di Puskesmas Ranomut Kecamatan Paal II Manado pada tanggal 4 April 2017 dari buku register laporan persalinan diperoleh data untuk tahun 2014 tercatat 94 persalinan. Dari jumlah tersebut ibu yang mengalami kejadian ruptur perineum $53(56 \%) \mathrm{ibu}$, dengan penyebab yaitu usia ibu 12 (23\%), paritas 25 (47\%), dan berat badan lahir 13 (24\%). Kemudian data tahun 2015 tercatat 177 persalinan, dari jumlah tersebut ibu yang mengalami ruptur perineum $100 \quad(56 \%)$ ibu, dengan penyebab yaitu usia ibu 28 (28\%), paritas 58 (58\%), dan berat badan lahir 26 (26\%). Beberapa informasi dari bidan-bidan yang bertugas di ruang KIA/KB Puskesmas Ranomuut Kecamatan
Paal II Manado yaitu kejadian ruptur perineum pada persalinan normal masih tergolong tinggi dan menyebabkan beberapa komplikasi diantaranya nyeri pasca persalinan bahkan infeksi.

Perdarahan postpartum menjadi penyebab utama $40 \%$ kematian ibu di Indonesia. Robekan jalan lahir merupakan penyebab kedua perdarahan setelah atonia uteri yang terjadi pada hampir persalinan pertama dan tidak jarang juga pada persalinan berikutnya ${ }^{(\mathbf{1})}$.

Ruptur perineum merupakan laserasi atau luka yang terjadi di sepanjang jalan lahir (perineum) akibat proses persalinan. Ruptur perineum dapat terjadi secara disengaja (episiotomi) atau tidak disengaja (2)

Ruptur perineum dapat dihindari atau dicegah dengan berbagai upaya pendekatan, penyuluhan bahkan anjuran kepada pasangan usia subur (PUS) sebelum hamil, selama dalam masa kehamilan, serta dala menghadapi proses persalinan. Untuk menghindari atau meminimalkan kejadian ruptur perineum, pasangan usia subur (PUS) diharapkan untuk tidak hamil pada usia $<20$ tahun dan > 35 tahun. Jika hamil dianjurkan untuk rutin memeriksakan kehamilannya, makan makanan bergizi sesuai kebutuhan ibu 
hamil, melakukan senam hamil sesuai dengan usia kehamilan ${ }^{(3)}$.

Penelitian yang sebelumnya dilakukan oleh Herdiani dan Trisnasari dengan judul faktor-faktor yang berhubungan dengan kejadian ruptur perineum spontan di RSUD Kebumen menunjukkan hasil ada hubungan faktor umur ibu, paritas dan berat badan lahir dengan kejadian ruptur perineum spontan pada persalinan normal di RSUD Kebumen ${ }^{(4)}$.

Penelitian yang dilakukan oleh Ariestanti dan Purwaningtias dengan judul "Analisis faktor - faktor yang berhubungan dengan kejadian ruptur perineum pada ibu bersalin" menunjukkan hasil ada hubungan yang signifikan antara faktor umur ibu, paritas, dan berat badan lahir dengan kejadian ruptur perineum pada persalinan normal ${ }^{(5)}$.

\section{METODE}

Penelitian ini adalah bersifat analitik dengan mengunakan desain penelitian retrospektif atau pengumpulan data sekunder. Dilaksanakan di Puskesmas Ranomut Kecamatan Paal II Manado pada bulan April 2017 sampai Agustus 2017. Penelitian ini menggunakan dua variabel, yaitu Variabel bebas (partus presipitatus, paritas dan berat badan lahir) dan Variabel terikat (ruptur perineum). Adapun populasi dari penelitian yaitu semua ibu bersalin normal tahun 2016 berjumlah $167 \mathrm{ibu}$ sebagai sampel atau subjek penelitian. Instrument yang digunakan adalah cheklist dan data diperoleh dari data sekunder. Analisis data yang digunakan adalah analisis univariat dan bivariat.

\section{HASIL}

a. Hasil Univariat

Tabel 1. Distribusi Frekuensi Berdasarkan Kejadian Rupture Perineum Di Puskesmas Ranomut Kecamatan Paal II Manado

\begin{tabular}{lcc}
\hline \multicolumn{1}{c}{ Karakteristik } & Jumlah & \\
\hline \multicolumn{1}{c}{ f } & $\%$ \\
\hline Partus presipitatus & 42 & 25 \\
$\quad$ Ya & 125 & 75 \\
$\quad$ Tidak & & \\
Paritas & 54 & 32 \\
$\quad$ Primipara & 113 & 68 \\
$\quad$ Multipara & 15 & \\
BBL & 137 & 82 \\
$\quad$ <2500 gr & 15 & 9 \\
2500-4000 gr & & \\
$\quad>4000$ gr & 109 & 65 \\
Kejadian Rupture perineum & 58 & 35 \\
$\quad$ Rupture & & \\
$\quad$ Tidak Rupture &
\end{tabular}


Berdasarkan Tabel 1, menunjukkan bahwa responden terbanyak adalah yang tidak mengalami partus presipitatus yaitu 125 (75\%), paritas terbanyak pada multipara yaitu $113(68 \%)$, BBL terbanyak

b. Hasil Bivariat

1) Hubungan partus presipitatus dengan kejadian ruptur perineum pada persalinan normal di Puskesmas Ranomut Kecamatan Paal II Manado 2016

Tabel 2.Hubungan Partus Presipitatus dengan Kejadian Ruptur Perineum pada Persalinan Normal di Puskesmas Ranomut Kecamatan Paal II Manado 2016

\begin{tabular}{|c|c|c|c|c|c|c|c|}
\hline \multirow{3}{*}{ Partus presipitatus } & \multicolumn{6}{|c|}{ Kejadian ruptur perineum } & \multirow{3}{*}{$\boldsymbol{P}$} \\
\hline & \multicolumn{2}{|c|}{$\begin{array}{l}\text { Terjadi } \\
\text { ruptur }\end{array}$} & \multicolumn{2}{|c|}{$\begin{array}{l}\text { Tidak terjadi } \\
\text { ruptur }\end{array}$} & \multicolumn{2}{|c|}{ Total } & \\
\hline & $\mathbf{N}$ & $\%$ & $\mathbf{N}$ & $\%$ & $\mathbf{N}$ & $\%$ & \\
\hline Ya & 37 & 88 & 5 & 12 & 42 & 100 & \multirow{3}{*}{0.000} \\
\hline Tidak & 70 & 56 & 55 & 44 & 125 & 100 & \\
\hline Jumlah & 107 & 144 & 60 & 56 & 167 & & \\
\hline
\end{tabular}

Berdasarkan tabel 2, menunjukkan yang tidak partus presipitatus. Hasil uji bahwa responden yang mengalami partus presipitatus lebih banyak mengalami rupture perineum dibandingkan dengan yang tidak rupture. Akan tetapi, sebagian besar jumlah responden yang mengalami rupture adalah pada BBL 2500-4000 gr ada 137 responden (82\%) dan dari 167 responden, terbanyak yang mengalami ruptur perineum yaitu $109(65 \%)$.

2) Hubungan paritas dengan kejadian ruptur perineum dalam proses persalinan normal di Puseksmas Ranomut Kecamatan Paal II Manado 2016

Tabel 3. Hubungan Paritas Dengan Kejadian Ruptur Perineum Pada Persalinan Normal Di Puskesmas Ranomut Kecamatan Paal II Manado 2016

\begin{tabular}{cccccccc}
\hline \multirow{3}{*}{ Paritas } & \multicolumn{9}{c}{ Kejadian Rupture Perineum } & \multirow{2}{*}{$\boldsymbol{P}$} \\
\cline { 2 - 7 } & \multicolumn{2}{c}{ Terjadi Rupture } & \multicolumn{2}{c}{ Tidak Terjadi Rupture } & \multicolumn{2}{c}{ Total } & \\
\cline { 2 - 7 } & $\mathrm{n}$ & $\%$ & $\mathrm{~N}$ & $\%$ & $\mathrm{n}$ & $\%$ & \\
\hline Primipara & 45 & 83 & 9 & 17 & 54 & 100 & 0,005 \\
Multipara & 65 & 58 & 48 & 42 & 113 & 100 & \\
\hline
\end{tabular}

Dari tabel 3, menunjukkan bahwa yang mengalami rupture perineum terbanyak adalah multipara yaitu $65(58 \%)$. Hasil uji statistik Chi-Square yaitu nilai $p$ (signifikasi) yang didapatkan adalah 0,005 atau nilai $p<0,05$ yang berarti terdapat hubungan yang bermakna antara paritas dengan kejadian ruptur perineum. 
3) Hubungan berat badan lahir dengan kejadian ruptur perineum dalam proses persalinan normal di Puskesmas Ranomut Kecamatan Paal II Manado 2016

Tabel 4. Hubungan Berat Badan Lahir Dengan Kejadian Ruptur Perineum Pada Persalinan Normal Di Puskesmas Ranomut Kecamatan Paal II Manado 2016

\begin{tabular}{|c|c|c|c|c|c|c|c|}
\hline \multirow{3}{*}{ Barat Badan Lahir } & \multicolumn{6}{|c|}{ Kejadian Rupture Perineum } & \multirow{3}{*}{$\boldsymbol{P}$} \\
\hline & \multicolumn{2}{|c|}{ Terjadi Rupture } & \multicolumn{2}{|c|}{ Tidak Terjadi Rupture } & \multicolumn{2}{|c|}{ Total } & \\
\hline & $\mathrm{N}$ & $\%$ & $\mathrm{~N}$ & $\%$ & $\mathrm{~N}$ & $\%$ & \\
\hline$<2500 \mathrm{gr}$ & 4 & 27 & 11 & 73 & 15 & 100 & \\
\hline $2500-4000 \mathrm{gr}$ & 90 & 66 & 47 & 34 & 137 & 100 & 0,003 \\
\hline$>4000 \mathrm{gr}$ & 15 & 100 & 0 & 0 & 15 & 100 & \\
\hline
\end{tabular}

Dari tabel 4, menunjukkan bahwa yang mengalami rupture perineum terbanyak adalah responden dengan 2500-4000 gr yaitu 90 (66\%). Hasil uji statistik Chi-Square yaitu nilai $p$ yang didapatkan adalah 0,003 atau nilai $p<0,05$ yang berarti terdapat hubungan yang bermakna antara berat badan lahir dengan kejadian ruptur perineum.

\section{PEMBAHASAN}

Berdasarkan hasil penelitian yang dilakukan di Puskesmas Ranomut Kecamatan Paal II Manado, didapati angka kejadian ruptur perineum yang masih tinggi. Dari 167 responden, terdapat $109 \quad(65 \%)$ yang mengalami rupture perineum dibanding dengan yang tidak mengalami rupture perineum yaitu $58(35 \%)$.

1. Karakteristik Responden Menurut kejadian partus presipitatus

Karakteristik responden menurut kejadian partus presipitatus di Puskesmas Ranomut Kecamatan Paal II Manado tahun 2016 menunjukkan bahwa responden terbanyak adalah responden yang tidak mengalami partus presipitatus yaitu 125 (75\%). Lama persalinan dapat mempengaruhi terjadinya rupture perineum. Hal ini atau terlalu lama ${ }^{(6)}$. Seperti pada kasus partus

presipitatus dapat menyebabkan ruptur perineum bahkan robekan serviks yang dapat mengakibatkan perdarahan pasca persalinan ${ }^{(7)}$.

2. Karakteristik Responden Menurut Paritas Karakteristik responden menurut paritas di Puskesmas Ranomut Kecamatan Paal II Manado tahun 2016 menunjukkan bahwa responden terbanyak adalah multipara yaitu 113 (68\%). Paritas mempunyai pengaruh terhadap kejadian ruptur perineum. Ibu primipara memiliki resiko lebih besar mengalami ruptur perineum daripada ibu dengan paritas lebih dari satu. Hal ini dikarenakan jalan lahir yang belum pernah dilalui oleh kepala bayi sehinggan otot-otot perineum belum meregang .

3. Karakteristik responden menurut Berat Badan Lahir ${ }^{(7)}$.

Karakteristik responden menurut Berat

Badan Lahir di Puskesmas Ranomut Kecamatan Paal II Manado tahun 2016 menunjukkan responden terbanyak adalah responden dengan BBL 2500-4000 gr yaitu 90 (66\%). Hal ini menunjukkan bahwa semakin besar berat bayi yang dilahirkan meningkatkan resiko terjadinya ruptur perineum, hal ini 
terjadi karena perineum tidak cukup kuat menahan regangan kepala bayi dengan berat badan bayi yang besar ${ }^{(7)}$.

4. Karakteristik Responden Menurut Kejadian Ruptur perineum

Dari 167 responden, yang mengalami rupture perineum yaitu 109 (65\%), dengan rupture spontan sebanyak 79 (72\%) dan episiotomi sebanyak 30 (28\%). Hal ini menunjukkan bahwa kejadian ruptur terbanyak adalah ruptur spontan dengan 79 (72\%), hal ini di sebabkan karna faktor lama persalinan, paritas dan berat badan lahir ${ }^{(7)}$.

5. Hubungan partus presipitatus dengan

Kejadian Ruptur Perineum Pada Persalinan Normal

Hasil penelitian menunjukkan bahwa responden yang mengalami partus presipitatus mengalami rupture perineum terbanyak dibanding yang tidak terjadi rupture perineum. Hasil uji statistik ChiSquare yaitu nilai $p$ (signifikasi) yang didapatkan adalah 0,000 atau nilai $p<0,05$ yang berarti terdapat hubungan yang bermakna antara partus presipitatus dengan kejadian ruptur perineum. Partus presipitatus dapat menyebabkan ruptur perineum bahkan robekan serviks yang dapat mengakibatkan perdarahan pasca persalinan. Persalinan yang terlalu cepat menyebabkan ibu mengejan kuat tidak terkontrol, kepala janin terjadi defleksi terlalu cepat. Keadaan ini akan memperbesar kemungkinan rupture perineum. Robekan spontan pada vagina atau perineum dapat terjadi saat kepala dan bahu dilahirkan. Kejadian robekan akan meningkat jika bayi dilahirkan terlalu cepat dan tidak terkendali .

6. Hubungan Paritas Dengan Kejadiaan Ruptur Perineum Pada Persalinan normal Ada hubungan signifikan antara paritas dengan kejadiaan rupture perineum pada persalinan normal. Hasil penelitian ini menunjukkan bahwa pada multipara terjadi ruptur terbanyak dibanding primipara, yaitu 65 (58\%). Hasil uji statistik Chi-Square yaitu nilai $p$ (signifikasi) yang didapatkan adalah 0,005 atau nilai $p<0,05$ yang berarti terdapat hubungan yang bermakna antara paritas dengan kejadian ruptur perineum. Hal ini sesuai dengan teori dari Prawirohardjo bahwa rupture perineum terjadi pada hampir semua persalinan pertama dan tidak jarang juga pada persalinan berikutnya dikarenakan pada primipara perineum utuh dan elastis, sedangkan pada multipara tidak utuh, longgar, dan lembek ${ }^{\left({ }^{(8)}\right.}$. Hasil penelitian yang dilakukan oleh Suryani menunjukkan bahwa ada hubungan paritas dengan kejadian rupture perineum dalam persalinan normal. Penyebab rupture perineum pada primipara karena kelenturan jan lahir / elastisitas perineum. Sedangkan penyebab rupture perineum pada multipara sebagian karena berat badan bayi baru lahir, kerapuhan perineum, dan asuhan sayang ibu yang kurang baik ${ }^{(9)}$.

7. Hubungan BBL Dengan Keadiaan Ruptur Perineum Pada Persalinanan Normal

Ada hubungan signifikan dengan antara BBL dengan kejadiaan ruptur perineum pada persalinan normal. Perolehan data dari penelitian ini menunjukkan kejadian ruptur perineum terbanyak pada responden dengan 
BBL 2500-4000 gr yaitu sebanyak 90 (66\%).

Hasil uji statistik Chi-Square yaitu nilai $p$ yang didapatkan adalah 0,003 atau nilai $p<0,05$ yang berarti terdapat hubungan yang bermakna antara berat badan lahir dengan kejadian ruptur perineum. Hal tersebut sesuai dengan teori dari Saifuddin bahwa semakin besar berat bayi yang dilahirkan meningkatkan resiko terjadinya ruptur perineum, hal ini terjadi karena perineum tidak cukup kuat menahan regangan kepala bayi dengan berat badan bayi yang besar ${ }^{(7)}$. Hasil penelitian yang dilakukan oleh Rosmawar menunjukkan bahwa ada hubungan berat badan lahir dengan kejadian rupture perineum pada persalinan normal. Berat badan janin > 4000 gr dapat

\section{DAFTAR PUSTAKA}

1. Kuswanti I. Askeb II Persalinan. Yogyakarta: Pustaka Pelajar; (2014).

2. Ambarwati E, Rismintari Y. Asuhan Kebidanan Komunitas. Yogyakarta: Nuha Medika; (2011).

3. Anggriyana. Senam Kesehatan. Yogyakarta: Nuha Medika; (2010).

4. Herdiani C, Trisnasari A. Faktor-Faktor yang Berhubungan dengan Kejadian Ruptur Perineum Spontan di RSUD Kebumen. J Kebidanan. (2013)

5. Ariestanti D, Purwaningtias E. Analisis Faktor - faktor yang Berhubungan dengan Kejadian Ruptur Perineum pada Ibu Bersalin. J Kebidanan. (2016); Volume IV,.

6. Oxorn H, Forte W. Ilmu Kebidanan: Patologi dan Fisiologi Persalinan. Hakimi M, editor. Yogyakarta: Andi Offset; (2010).

7. Saifuddin A. Buku Acuan Nasional Pelayanan Kesehatan Maternal dan Neonatal. Jakarta: Yayasan Bina Pustaka Sarwono Prawirohardjo; (2008).

8. Prawirohadjo S. Ilmu Kebidanan. Jakarta: PT. Bina Pustaka Sarwono Prawirohardjo; (2014).

9. Suryani. Factor-Faktor yang Berhubungan dengan Rupture Perineum pada Persalinan Normal di Rumah Bersalin Atiah. J Kesehat. (2013)

10. Rosmawar C. Faktor-Faktor yang Mempengaruhi Terjadinya Laserasi pada Persalinan Normal di Puskesmas Tanah Jambo Aye Panton Labu. J Ilm Stikes. (2013) 